$18,1 \%$ số đối tượng sử dụng ma túy tại vũ trường trước khi bị ngộ độc.Trước khi ngộ độc lần này, phần lớn đối tượng sử dụng ma túy vào ban đêm, chiếm $72,2 \%$ và hơn một nửa số đối tượng sử dụng ma túy cùng người khác $(62,5 \%)$. Có thể thấy rằng, ngộ độc ma túy có thể xảy ra ở bất cứ thời gian, địa điểm nào, dù sử sử dụng một mình hay cùng người khác. Nhiều người sử dụng tới khi kiệt sức và sử dụng liêu sau ngay khi liều trước đó hết hoặc giảm tác dụng bất kể thời gian.

\section{KẾT LUÂN}

Đặc điểm về dịch tễ của các bệnh nhân ngộ độc ma túy mới, không phải nhóm opi:

Chủ yếu gặp ở Nam giới $(72,2 \%)$, Nữ giới 27,8\%,tỉ lệ Nam/Nữ 2,6:1; Tuổi trung bình là $30,57 \pm 9,3$ tuổi; người thất nghiệp 73,6\%; trình độ trung học phố thông trở xuống $(65,3 \%)$; người độc thân $65,3 \%$; sổng ở thành phố $59,7 \%$ và nông thôn 40,3\%.

Một số loại ma túy mới thường gặp là Amphetamin $(29,2 \%)$, MET $(22,2 \%)$, MDMA $(19,4 \%)$, THC $(20,8 \%)$, Ketamin $(8,3 \%)$; chủ yêuu bệnh nhân dùng đường uống $(79,2 \%)$, đường hút, hít là 20,8\%.

Bệnh nhân dùng ma túy do nghiện $(54,2 \%)$, được rủ $(26,4 \%)$, do thói quen $(19,4 \%)$; sử dụng tại vũ trường và địa điểm đông người $(58,3 \%)$, tại nhà $(41,7 \%)$; thường dùng vào ban đêm $(72,2 \%)$; dùng cùng người khác $(62,5 \%)$. Có $81,9 \%$ đã từng sử dụng ma túy trước đó và 18,1\% ngộ độc ở lần đầu sử dụng.

\section{TÀI LIỆU THAM KHẢO}

1. Nguyễn Thanh Long và và công sự (2010). "Hành vi nguy cơ lây nhiếm và tỉ lệ nhiếm HIV trong nhóm nghiên chích ma túy tại khu vực nông thôn miền núi tỉnh Bắc Giang, năm 2010". Tạp chí Y học thực hành, số 742-743: 197-200

2. Nguyễn Thị Du (2004). Định hướng chung chẩn đoán và xứ trí ngộ độc cấp, Tư vấn chẩn đoán và xử trí nhanh ngộ độc cấp. Nhà xuất bản $Y$ học Hà Nội. 2004; 9-22.

3. Rasmussen N. (2011)."Medical science and the military: the Allies' use of amphetamine during World War II". J Interdiscip Hist, 42(2): 205-33.

4. Gainza I., Nogue $S$., Martinez Velasco $C_{\text {., }}$ et al (2003), "Drug poisoning", An Sist Sanit Navar, 26 (1): 99-128.

5. David Sulzer, Mark S. Sonders, Nathan W. Poulsen et al (2005). "Mechanisms of neurotransmitter release by amphetamines: A review". Progress in Neurobiology, 75(6): 406-433.

6. Wilson A (2008), "Mixing the Medicine: The unintended consequence of amphetamine control on the Northern Soul Scene", Internet Journal of Criminology.

7. George Sam Wang (2020), "Cannabis (marijuana): Acute intoxication", Uptodate 2020.

\title{
TÌNH HÌNH TRẦM CẢM VÀ MộT Số YẾU TỐ LIÊN QUAN Ở NGƯỜ'I DÂN QUÂAN NINH KIỀU, THÀNH PHỐ CẦN THO'
}

\author{
Nguyễn Tấn Đạt*, Hồ Thế Nhân*, Dương Phúc Lam*, \\ Nguyễn Minh Phương*, Nguyễn Trung Kiên*
}

\section{TÓM TẮT}

Đặt vấn đê: Trâm cảm làm gia tăng nhu câu chăm sóc sức khỏe, giảm chất lượng cuộc sống và có nguy cơ tự tử cao. Mục tiêu nghiên cứu: Xác định tỷ lệ trầm cảm và một yếu tố liên quan đến trầm cảm ở người trưởng thành tại thành phố Cần Thơ. Đối tượng và phương pháp nghiên cứu: Nghiên cứu mô tả cắt ngang có phân tích trên 449 người từ 18-60 tuổi tại quận Ninh Kiều, thành phố Cân Thơ từ tháng 9/2016 đến 6/2017. Trầm cảm được đo lường dựa trên thang điểm PHQ-9. Tổng điểm 9 mục dao động từ 0 đến 27 điểm. Tổng điểm $5,10,15,20$ tương ứng với các điểm cắt mức độ trầm cảm nhẹ, vừa, nặng, rất

*Trường Đại học Y Dước Cần Tho

Chịu trách nhiệm chính: Nguyễn Tấn Đạt

Email: ntdat@ctump.edu.vn

Ngày nhận bài: 2.3.2021

Ngày phản biên khoa hoc: 27.4.2021

Ngày duyệt bài: 10.5.2021 năng. Kết quả: 16\% đối tượng tham gia nghiên cứu mắc trầm cảm, với điểm cắt từ 5 trở lên. Có $76,4 \%$ đối tượng trầm cảm nhẹ; $18,1 \%$ vừa; $4,1 \%$ nặng vừa; $1,4 \%$ nặng. Bệnh mạn tính $(O R=2,79 ; p=0,005)$, tính cách trầm tính/dễ xúc đông $(\mathrm{OR}=3,12 ; \mathrm{p}=0,002)$, thất bại trong công việc/học tập ( $O R=4,40 ; p<0,001)$; tiền sứ gia đình có người bi tâm thần $(\mathrm{OR}=8,93$; $\mathrm{p}=0,029)$, gia đình không hạnh phúc $(\mathrm{OR}=5,61$; $\mathrm{p}=0,002)$, người thân mất/bểnh năng $(\mathrm{OR}=2,75$; $\mathrm{p}=0,004)$ được tìm thấy có ý nghĩa thổng kê liên quan đến trầm cảm. Kết luận: Nghiên cứu này cung cấp một tín hiệu báo động cho các chuyên gia y tế và các nhà hoach định chính sách y tế tai thành phố Cần Thơ sự cần thiết việc phát hiện tốt hởn về bệnh trầm cảm và các yếu tố liên quan ở người trưởng thành.

Tư khóa: trầm cảm, yếu tố liên quan, Ninh Kiều, Cần Thơ.
SUMMARY
DEPRESSION AND ITS ASSOCIATED FACTORS AMONG ADULTS IN NINH KIEU 


\section{DISTRICT CAN THO CITY}

Background: Depression results in an increase of the health-seeking behavior, decreased quality of life and high risk of suicidal tendencies. Objectives: The aim of this study was to estimate the prevalence of depression and its associated factors among community adults in urban Can Tho City, Vietnam. Materials and methods: A cross-sectional descriptive study with an analytic component was conducted among 449 people from 18 to 60 years old in Ninh Kieu district, Can Tho City during Sep 2016 until June 2017. Depression was measured using the Patient Health Questionnaire-9 scale. PHQ-9 total score for the nine items ranges from 0 to 27. Scores of $5,10,15$, and 20 represent cutoff points for mild, moderate, moderately severe and severe depression, respectively. Results: Sixteen percent of participants meeting the cutoff point for depression, score of 5 or over. There were $76.4 \%$ with mild, $18.1 \%$ with moderate, $4.1 \%$ with moderately severe and $1.4 \%$ severe depression. Chronic diseases $(\mathrm{OR}=2.79$; $\mathrm{p}=0.005)$, introvert/affective $(\mathrm{OR}=3.12 ; \mathrm{p}=0.002)$, failure in work/study $(O R=4.40 ; p<0.001)$, family history of mental illness $(O R=8.93 ; p=0.029)$, family unhappiness $(\mathrm{OR}=5.61 ; \mathrm{p}=0.002)$, and relatives died/severe illness $(O R=2.75 ; p=0.004)$ were found statistically significant associated to depression. Conclusion: This study provides an alarming signal for health professionals and health policy maker in Can Tho City for the need of better recognition of depression and its associated factors in adult people. Can Tho.

Keywords: depression, related factors, Ninh Kieu,

\section{I. ĐẶT VẤN ĐỀ}

Bệnh trầm cảm ngày nay là một trong những rối loạn tâm thần phổ biến và có xu hướng ngày càng tăng ở nhiều nước trên thế giới. Trầm cảm là bệnh rối loạn về khí sắc, có những đăcc điểm chung như tâm trạng u uất, mất đi sự thích thú hoặc niềm vui, năng lượng hoạt động giảm sút, cảm thấy tội lối hoặc tự ti về bản thân, giấc ngủ hoặc khẩu vị bị xáo trộn, và khả năng tập trung kém... Các vấn đề trên có thể trở thành mãn tính hoặc tái phát thường xuyên và dẫn tới mất khả năng duy trì các thói quen sinh hoạt và làm việc hằng ngày. Trong tình huống xấu nhất, trầm cảm có thể dẫn đến tự tử [4]. Theo Tổ chức y tế thế giới, trong năm 2015 có khoảng 322 triệu người trên thế giới hiện đang sống với trầm cảm, ước tính $4,4 \%$ dân số toàn câu, tăng $18,4 \%$ trong khoảng từ năm 2005 đến năm 2015, mỗi năm trung bình có hơn 800.000 người tử vong do bệnh trầm cảm [9]. Xuất phát từ thực tế trên chúng tôi tiến hành đề tài với 2 mục tiêu sau: 1) Xác định tỷ lệ trầm cảm của người dân 18-60 tuổi tại quận Ninh Kiều, thành phố Cần Thơ năm 2016; 2) Tìm hiểu các yếu tố liên quan đến trầm cảm của người dân 18-60 tuổi tại quận Ninh Kiều, thành phố Cần Thơ năm 2016.

\section{II. ĐỐI TƯợNG VÀ PHƯƠ'NG PHÁP NGHIÊN CỨU}

Tiêu chuẩn chon mẫu: Người dân từ 18-60 tuổi có hộ khẩu thường trú tại địa bàn quận Ninh Kiều, thành phố Cần Thơ và đồng ý tham gia nghiên cứu..

Tiêu chuẩn loại trừ: Tình trạng sức khỏe của đối tượng không có khả năng trả lời được phỏng vấn như mắc bệnh thần kinh thực thể, tâm thần phân liệt,...; Người bị dị tật không có khả năng giao tiếp; Đối tượng đang nằm viện, bị giam giữ, đi làm ăn hay công tác xa.

Thời gian và địa điểm nghiên cứu: từ tháng 9 năm 2015 đến tháng 6 năm 2016. Tại các hộ gia đình hộ khẩu thường trú trên địa bàn quận Ninh Kiều, Cần Thơ.

Thiết kế nghiên cứu: Nghiên cứu mô tả cắt ngang có phân tích.

Cỡ mâ̂u: Áp dụng công thức tính cõ̃ mẫu ước lượng một tỉ lệ

$$
n=Z_{1-\alpha / 2}^{2} \frac{p(1-p)}{d^{2}}
$$

Trong đó: $n$ là cõ̃ mẫu nhỏ nhất hợp lý; z: trị số phân phối chuẩn, với độ tin cậy $95 \%$, ta có $\mathrm{Z}=1,96 ; d=0,03$. Chọn $p=0,048$ ước lượng theo kết quả nghiên cứu Kim Bảo Giang [2]. Thay số vào công thức trên ta được $n=196$ đối tượng. Do phương pháp chọn mẫu nhiều giai đoạn nên để đảm bảo tính đại diện cho quần thể nghiên cứu, chúng tôi sử dụng hiệu lực thiết kế của nghiên cứu là 2 và cộng thêm khoảng $5 \%$ ước tính cho dữ liệu khuyết, cõ mẫu nghiên cứu tối thiểu 402. Thực tế số mấu thu được trong nghiên cứu sau khi đã loại bỏ những phiếu không hợp lệ là 449 đối tượng.

Phướng pháp chọn mẫu: phương pháp chọn mẫu nhiều giai đoạn: quận Ninh Kiều có 13 phường, chọn ngầu nhiển bằng cách bốc thăm 5 phường; từ 5 phường chọn ngẫu nhiên 3 khu vực; mối khu vực chọn ngẫu nhiên 30 hộ gia đình.

Nội dung nghiên cứu và phương pháp thu thập số liệu. Nghiên cứu sử dụng bộ câu hỏi phỏng vấn trực tiếp đối tượng để thu thập những biến số đáp ứng các nội dung nghiên cứu:

- Tình hình trầm cảm chung ở người dân 1860 tuổi: đánh giá dựa trên thang đo trầm cảm PHQ-9 (Patient Health Questionnaire-9) được xây dựng theo tiêu chuẩn chẩn đoán trầm cảm DSM IV, tổng điểm dao động từ 0 đến 27 điểm, phân loại trầm cảm: 1-4 điểm (không trầm cảm); 5-9 điểm (trầm cảm nhẹ); 10-14 điểm (vừa), 15-19 điểm (nặng vừa), 20-27 điểm (nặng). Thang đo được sử dụng trong nhiều nghiên cứu trong và ngoài nước [2], [7], [8]. 
- Một số yếu tố liên quan đến trầm cảm được nhận định theo mô hình từ cá nhân đến gia đình, mở rộng hơn là cộng đồng, xã hội.

Phương pháp xử lý số liệu: Phân tích số liệu bằng phần mềm SPSS 18.0. Kết quả được thể hiện dưới dạng tần số, tỷ lệ phần trăm (\%), tỷ số chênh (OR), khoảng tin cậy 95\% (KTC $95 \%$ ) của OR; kiểm định X2 với mức ý nghĩa $a=$ 0,05 được lấy để xem xét sự khác biệt có ý nghĩa thống kê khi $p<0,05$. Hồi quy logistic đa biến được sử dụng để loại bỏ các biến nhiễu không tham gia vào mô hình giải thích cho biến phụ thuộc.

\section{KẾT QUẢ NGHIÊN CỨU}

3.1. Đặc điểm chung của đôi tượng nghiên cứu

\begin{tabular}{|c|c|c|c|}
\hline \multicolumn{2}{|c|}{ Đặc điếm chung } & Tân số & Tỷ lệ (\%) \\
\hline \multirow{2}{*}{ Giới tính } & Nam & 193 & 43 \\
\cline { 2 - 4 } & Nữ & 256 & 57 \\
\hline \multirow{4}{*}{ Tuổi } & $18-29$ & 74 & 16,5 \\
\cline { 2 - 4 } & $30-39$ & 133 & 29,6 \\
\cline { 2 - 4 } & $40-49$ & 103 & 22,9 \\
\cline { 2 - 4 } & $50-60$ & 139 & 31 \\
\hline \multirow{2}{*}{$\begin{array}{c}\text { Trình độ } \\
\text { học vấn }\end{array}$} & Tữ dưới THCS & 249 & 55,5 \\
\hline Tống & Trên THCS & 200 & 44,5 \\
\hline Tốn & & $\mathbf{4 4 9}$ & $\mathbf{1 0 0}$ \\
\hline
\end{tabular}

Nữ chiếm tỷ lệ $57 \%$, cao hơn nam (43\%). Độ tuổi tâp trung nhiều ở nhóm 50-60 (31\%), 30-39 $(29,6 \%)$. Trình độ học vấn đối tượng dưới THCS là $55,5 \%$.

3.2. Tình hình trâm cảm ở người dân 1860 tuổi tại quận Ninh Kiều

Bảng 1. Tình hình trầm cảm ở người dân

\begin{tabular}{|c|c|c|}
\hline Tình hình trâm cảm & Tân số & Tỷ lệ (\%) \\
\hline Không trầm cảm & 377 & 84 \\
\hline Trầm cảm & 72 & 16 \\
\hline Tống & $\mathbf{4 4 9}$ & $\mathbf{1 0 0}$ \\
\hline
\end{tabular}

Bảng 2. Mức độ trầm cảm ở người dân \begin{tabular}{|l|l|l|}
\hline Mức đồ trâm cảm & Tân số & Tỷ lê (\%) \\
\hline
\end{tabular}

\begin{tabular}{|c|c|c|}
\hline Nhe & 55 & 76,4 \\
\hline Vưa & 13 & 18,1 \\
\hline Nặng vừa & 3 & 4,1 \\
\hline Nă̆ng & 1 & 1,4 \\
\hline Tống & $\mathbf{7 2}$ & $\mathbf{1 0 0}$ \\
\hline
\end{tabular}

Có 16\% (72/449) đối tượng được chẩn đoán trầm cảm. Trong số 72 đối tượng trầm cảm, $76,4 \%$ có biểu hiện trầm cảm ở mức độ nhẹ 18,1\% mức độ vừa, 5,5\% mức độ nặng.

3.3. Một số yếu tố liên quan với trâm cảm. Sau khi phân tích đớn biến, chúng chọn 19 biến độc lập có liên quan đến trầm cảm với $\mathrm{p}<0,1$ như: yếu tố cá nhân (giới tính, trình độ học vấn, mắc bệnh mạn tính, tính cách vui vẻ lạc quan, biến cố bản thân trong công việc/học tập, tình yêu/hôn nhân); yếu tố gia đình (kinh tế gia đình, tiền sử gia đình có người mắc bệnh tâm thần, sự quan tâm chia sẻ của gia đình, biến cố liên quan đến người thân), yếu tố cộng đồng xã hội (công việc căng thẳng, mâu thuẫn người xung quanh, áp lực tiền bạc, tham gia hoạt động công tác xã hội). Các biến này được đưa vào mô hình hồi quy logistic đa biến nhằm kiểm soát các yếu tố gây nhiếu không tham gia vào mô hình giải thích cho biến phụ thuộc (trầm cảm). Tất cả các biến được đưa vào xử lý cùng lúc bằng phương pháp Backward Wald.

Bảng 3. Phân tích hồi quy logistic đa biến xác định yêu tố liên quan đến tràm cảm

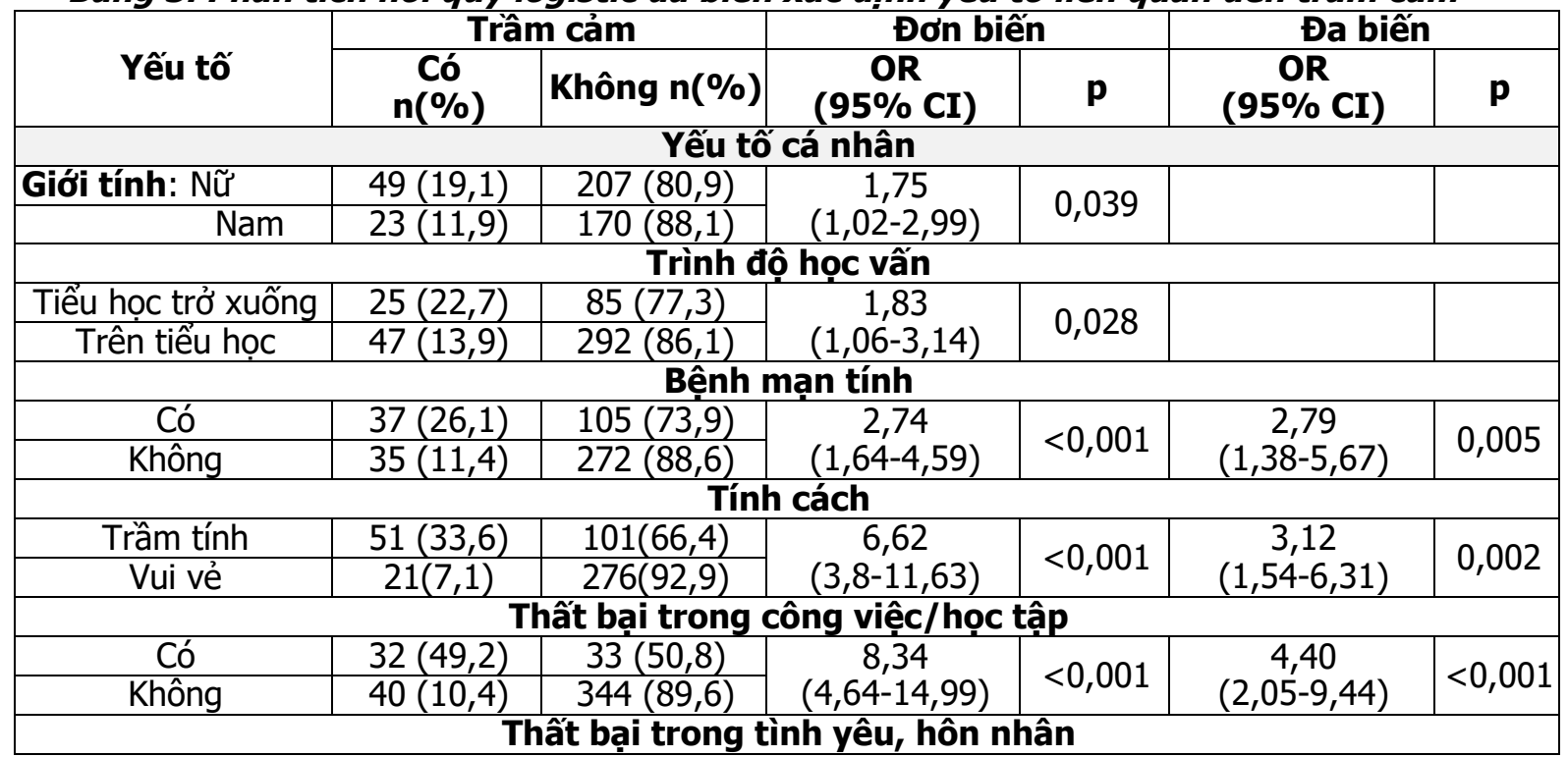




\begin{tabular}{|c|c|c|c|c|c|c|}
\hline $\begin{array}{c}\text { Có } \\
\text { Không } \\
\end{array}$ & $\begin{array}{c}6(37,5) \\
66(15,2)\end{array}$ & $\begin{array}{c}10(62,5) \\
367(84,8) \\
\end{array}$ & \multirow{2}{*}{$\begin{array}{c}3,34 \\
(1,17-9,49) \\
\text { hôn nhân }\end{array}$} & 0,029 & & \\
\hline \multicolumn{6}{|c|}{ Tình trạng hốn nhân } & \\
\hline Kết hôn & $45(13,4)$ & $290(86,6)$ & 2,00 & \multirow{2}{*}{0,01} & & \\
\hline Ly dị/ly thân & $27(23,7)$ & $87(76,3)$ & $(1,17-3,41)$ & & & \\
\hline \multicolumn{7}{|c|}{ Yếu tố gia đình } \\
\hline \multicolumn{7}{|c|}{ Kinh tế gia đình } \\
\hline Nghèo/cận nghèo & $10(52,6)$ & $9(47,4)$ & 6,60 & \multirow{2}{*}{$<0,001$} & & \\
\hline Không nghèo & $62(14,4)$ & $368(85,6)$ & $(2,58-16,88)$ & & & \\
\hline \multicolumn{7}{|c|}{ Tiền sử gia đình có người bệnh vế tâm thân } \\
\hline Có & $6(66,7)$ & $3(33,3)$ & 11,36 & \multirow{2}{*}{0,001} & 8,93 & \multirow{2}{*}{0,029} \\
\hline Không & $66(15)$ & $373(85)$ & $(2,76-45,45)$ & & $(1,25-63,69)$ & \\
\hline \multicolumn{7}{|c|}{ Hạnh phúc gia đình } \\
\hline Không & $26(76,5)$ & $8(23,5)$ & 26,32 & \multirow{2}{*}{$<0,001$} & 5,61 & \multirow{2}{*}{0,002} \\
\hline Có & $46(11,1)$ & $369(88,9)$ & $(11,1-62,5)$ & & $(1,85-17,02)$ & \\
\hline \multicolumn{7}{|c|}{ Sự quan tâm chia sẻ của gia đình } \\
\hline Hiếm khi & $60(20,9)$ & $227(79,1)$ & 3,30 & $<0001$ & & \\
\hline Luôn luôn & $12(7,4)$ & $150(92,6)$ & $(1,72-6,33)$ & $<0,001$ & & \\
\hline \multicolumn{7}{|c|}{ Người thân mất/bệnh nặng } \\
\hline Có & $36(27,1)$ & $97(72,9)$ & \multirow{2}{*}{$\begin{array}{c}2,89 \\
(1,72-4,84) \\
\end{array}$} & \multirow{2}{*}{$<0,001$} & 2,75 & \multirow{2}{*}{0,004} \\
\hline Không & $36(11,4)$ & $280(88,6)$ & & & $(1,37-5,53)$ & \\
\hline \multicolumn{7}{|c|}{ Người thân thất bại trong công việc/học tập } \\
\hline Có & $16(40)$ & $24(60)$ & \multirow{3}{*}{$\begin{array}{c}4,20 \\
(2,10-8,40) \\
\text { ia đình lv thâ }\end{array}$} & \multirow{2}{*}{$<0,001$} & & \\
\hline Không & $56(13,7)$ & $353(86,3)$ & & & & \\
\hline \multicolumn{6}{|c|}{ Người thân trong gia đình ly thân/ly dị } & \\
\hline Có & $8(61,5)$ & $5(38,5)$ & \multirow{3}{*}{$\begin{array}{c}9,30 \\
(2,95-29,32) \\
\text { ưới chunq qia }\end{array}$} & \multirow{2}{*}{$<0,001$} & & \\
\hline Không & $64(14,7)$ & $372(85,3)$ & & & & \\
\hline & & thuân với I & & dình & & \\
\hline Có & $26(33,3)$ & $52(66,7)$ & 3,53 & & & \\
\hline Không & $46(12,4)$ & $325(87,6)$ & $(2,01-6,20)$ & $<0,001$ & & \\
\hline & & Yếu tố cộ & đồng-xã hội & & & \\
\hline & & Căng thắng & ong công việ & & & \\
\hline Có & $34(24,6)$ & $104(75,4)$ & 2,35 & & & \\
\hline Không & $38(12,2)$ & $273(87,8)$ & $(1,40-3,93)$ & 0,001 & & \\
\hline & & u thuấn hàr & xóm/đồng ng & iệp & & \\
\hline Có & $9(37,5)$ & $15(62,5)$ & 3,45 & & & \\
\hline Không & $63(14,8)$ & $362(85,2)$ & $(1,45-8,20)$ & 0,007 & & \\
\hline & Tha & gia các hoa & ộng công tác & xã hội & & \\
\hline Có & $62(17,7)$ & $289(82,3)$ & 1,89 & 0075 & & \\
\hline Không & $10(10,2)$ & $88(89,8)$ & $(0,93-3,84)$ & $0,0 / 5$ & & \\
\hline & & lực tiền be & lo cho cuộc s & & & \\
\hline Có & $13(56,5)$ & $10(43,5)$ & 8,09 & $<0001$ & & \\
\hline Không & $59(13,8)$ & $367(86,2)$ & $(3,39-19,28)$ & $<0,001$ & & \\
\hline Tống & $72(16)$ & $377(84)$ & & & & \\
\hline
\end{tabular}

Trong 19 biến độc lập được đưa vào phân tích hồi quy logistic đa biến thì có 07 biến sau được xác định là yếu tố liên quan thật sự có ý nghĩa thống kê đến bệnh trầm cảm, bao gồm: Bệnh mạn tính $(O R=2,79 ; p=0,005)$; Tính cách bản thân, nhóm trầm tính, nhạy cảm có nguy cơ trầm cảm cao hơn nhóm đối tượng tính cách vui vẻ, lạc quan $(\mathrm{OR}=3,12 ; \mathrm{p}=0,002)$. Những biến cố bản thân, nhóm đối tượng từng thua lồ kinh doanh/thất bại trong công việc/học tập có nguy cơ trầm cảm cao hơn nhóm không có $(\mathrm{OR}=4,40$; $\mathrm{p}<0,001)$. Tiền sử gia đình có người mắc bệnh về tâm thần, nhóm có tiền sử gia đình mắc bệnh về tâm thần có nguy cơ trầm cảm cao hơn nhóm không có $(\mathrm{OR}=8,93 ; p=0,029)$. Hạnh phúc gia đình, nhóm đối tượng gia đình không hạnh phúc có nguy cơ trầm cảm cao hơn so với nhóm đối tượng gia đình hạnh phúc $(O R=5,61 ; p=0,002)$. 
Nhóm đối tượng có người thân mất/bệnh nặng có nguy cơ trầm cảm cao hơn nhóm không có $(\mathrm{OR}=2,75 ; \mathrm{p}=0,004)$.

\section{BÀN LUÂN}

4.1. Tình hình trâm cảm của đối tượng. Qua nghiên cứu trên 449 đối tượng với thang đo sàng lọc trầm cảm $\mathrm{PHQ}-9$, kết quả nghiên cứu chúng tôi có 72/449 đối tượng mắc trâm cảm, chiếm tỷ lệ $16 \%$. Trong đó, phần lớn đối tượng biểu hiện trầm cảm mức nhẹ $76,4 \%$, trầm cảm vừa là $18,1 \%$, trầm cảm nặng vừa $4,1 \%$, trầm cảm nă̆ng $1,4 \%$. Nghiên cứu của chúng tôi cho tỷ lệ trầm cảm cao hơn nghiên cứu của Kim Bảo Giang, Nguyễn Nguyên Ngọc (2013), với tỷ lệ trầm cảm chung ở 3 thành phố (Hà Nội-Huế-Cần Thơ) là 4,8\%. Tại Cần Thơ và Huế, tỷ lệ trâm cảm nhe chiếm đa số lần lượt là $91,7 \%$ và $84,2 \%$; còn lại là trầm cảm vừa. Trong khi ở Hà Nội tỷ lệ trầm cảm nhe và vừa là tương đương nhau $(58,3 \%$ và $41,7 \%)[2]$. Nghiên cứu của chúng tôi ghi nhận tỷ lệ trầm cảm cao hơn, biểu hiện ở nhiêu mức độ hơon (nhẹ, vừa, nặng vừa, nặng). Có thể lý giải sự khác biệt này là do nghiên cứu chúng tôi tiển hành mang tính cập nhật hơn, tỷ lệ bệnh trâm cảm gia tăng phù hợp xu hướng chung của thế giới, ngoài ra còn các yếu tố vùng địa dư khác nhau, dẫn đến môi trường nơi sinh sống, nơi làm việc, điều kiện xã hội khác nhau.

4.2. Một số yếu tố liên quan đến trâm cảm. Theo kết quả nghiên cứu của chúng tôi, trong số 142/449 đối tượng từng cảm thấy lo lắng vì căn bệnh mạn tính của mình thì có đến 26,1\% đối tượng bị trầm cảm, cao gấp 2,79 lần nhóm không có bệnh mạn tính, sự khác biệt này có ý nghĩa thống kê. Tỷ lệ trầm cảm ở nhóm đối tượng mắc bệnh đau nửa đầu là cao nhất $37,5 \%$, sau đó nhóm bị bệnh tiêu hóa $30 \%$ và nhóm bệnh đái tháo đường $28,6 \%$. Kết quả tương tự ở nghiên cứu của Kim Bảo Giang đối tượng mắc bệnh mãn tính có nguy cơ trầm cảm cao hơn so với đối tượng không mắc bệnh (có ý nghĩa thống kê); tỷ lệ trầm cảm ở nhóm bệnh đái tháo đường và nhóm bệnh ung thư/tâm thần là cao nhất $(14,3 \%)$ [2]. Theo nghiên cứu của Nguyễn Thanh Cao thì tỳ lệ trầm cảm ở nhóm bị bệnh đau nữa đầu là cao nhất $(20,8 \%)$, sau đó là nhóm bệnh đái tháo đường $(17,9 \%)$ [1]. Theo Boris Voinv (2013) ghi nhận trầm cảm xảy ra ở $23 \%$ bệnh nhân sau nhồi máu cơ tim, 20-60\% bệnh nhân sau đột quy, cứ 4 người bệnh đái tháo đường thì có 1 người bị trầm cảm sau thời gian 2,5 năm, tình trạng trầm cảm tiến triển mãn tính, thường xuyên tái phát. Những bệnh nhân mắc bệnh mạn tính thường phải lo lắng vì tình hình bệnh tật của mình, phải sống cùng bệnh, phải điều trị thời gian dài, cùng những chi phí cho việc điều trị làm tăng nguy cơ xảy ra trầm cảm.

Tính cách vui vẻ, lạc quan là một trong số các yếu tố bảo vệ, hạn chế nguy cơ mắc bệnh trầm cảm, tỷ lệ trầm cảm ở nhóm đối tượng này là $7,1 \%$ thấp hơn nhóm còn lại $(33,6 \%)$, sự khác biệt có ý nghĩa thống kê. Những người có tâm lý trầm tính, dễ xúc động, nhạy cảm thường có nguy cơ bị choáng váng trước những biến cố trong cuộc sống. Ho sẽ trở nên tự tị, mặc cảm hoặc luôn đặt mình trong tư thế phản kháng, công kích lại người khác. Càng ngày họ sẽ càng trở nên cô lập và theo đó là mức độ trầm cảm ngày càng tăng, càng trở nên nguy hiểm [4]. Những biến cố trong cuộc sống mà đối tượng gặp phải làm gia tăng nguy cơ trầm cảm như: thua lỗ trong kinh doanh, thất bại trong công việc/học tập $(\mathrm{OR}=4,40, \mathrm{p}<0,001)$. Có thể lý giải đây là những cú sốc tâm lý lớn bản thân mỗi phải tự đương đầu để vượt qua nếu không sẽ dễ dàng gục ngã, mất hết ý chí, nghị lực phấn đấu. Cuộc sống dần trở nên chán nản, bế tắc, không còn động lực sống là những nguy cơ cao dẫn đến trầm cảm.

Theo nghiên cứu của chúng tôi, nhóm đối tượng có tiền sử gia đình có người bệnh về tâm thần có nguy cơ mắc bệnh trầm cảm cao hơn gấp 8,93 lần nhóm đối tượng gia đình không có người mắc bệnh, sự khác biệt có ý nghĩa thống kê. Theo nghiên cứu của Kim Bảo Giang cũng đã ghi nhận tỷ lệ trầm cảm ở người có tiền sử gia đình bệnh về tâm thần $(8,8 \%)$ cao gấp 2 lần so với người không có $(4,3 \%)$, tuy nhiên khác biệt không có ý nghĩa thống kê [2]. Một số nghiền cứu khác ghi nhận trong số $50 \%$ số người mắc bênh trầm cảm thì có ít nhất môt người bố hoặc me mắc trầm cảm. Nếu cả bố và me bị rối loạn trầm cảm thì có tới $50-70 \%$ trường hợp con cái họ cũng mắc bênh [4], [6].

Về hạnh phúc gia đình, nhóm đối tượng cảm nhận gia đình mình không hạnh phúc $(76,5 \%)$ có nguy cơ trầm cảm cao hơnn gấp 5,61 lần nhóm gia đình hạnh phúc $(11,1 \%)$, khác biệt có ý nghĩa thống kề. Bên cạnh đó, chúng tôi cũng ghi nhận được kết quả nhóm người hiếm khi nhận được sự quan tâm chia sẻ có nguy cơ trầm cảm cao hơn nhóm được quan tâm chia sẻ, tuy nhiên sự khác biệt chưa có ý nghĩa thống kê. Cuộc sống gia đình không hạnh phúc với những cau có, giận hờn, những nổi niềm tâm sự không thể giải bày, đó là những sức ép đẩy chúng ta 
vào những bế tắc và khủng hoảng [4], [6].

Nhóm các đối tượng đã từng gặp những sang chấn liên quan đển người thân: người thân mất/bênh nă̆ng; người thân bị thất bại trong công việc, người thân ly dị/ly thân, mâu thuẫn những người thân trong gia đình có tỷ lệ trầm cảm cao hơn hẳn những nhóm còn lại. Chúng tôi ghi nhận biến cố người thân mất hoặc bệnh nặng làm gia tăng nguy cơ trầm cảm ở đối tượng với sự khác biệt có ý nghĩa thống kê $(p=0,004)$. Thep Nguyễn Thị Thanh Mai (2011) đã tiến hành nghiên cứu theo dõi dọc sự thay đổi trâm cảm ở cha mẹ có trẻ bị ung thư trong quá trình điều trị. Sự việc đứa con thân yêu của mình bị bệnh ung thư đã gây ra một sang chấn tâm lý (stress) cực kỳ mạnh cho cha mẹ. Tại thời điểm chẩn đoán (1-4 tuần sau chẩn đoán) thì $100 \%$ số cha me mắc rối loạn trầm cảm, trong đó $88,5 \%$ ở mức vừa và năng. Tai thời điểm 6 tháng sau chẩn đoán vẫn còn $80 \%$ số cha mẹ bị trâm cảm [5].

\section{KẾT LUẬN VÀ KIẾN NGH!}

Trầm cảm là bệnh khá phổ biến ở người dân 18-60 tuổi tại quận Ninh Kiều, thành phố Cần Thơ. Đối tượng có nguy cơ mắc trầm cảm là người có bệnh mạn tính; tính cách trâm tính dễ xúc động, nhạy cảm; người từng trải qua biến cố lớn trong cuộc sống (thất bại trong công việc, người thân yêu mất/bệnh nặng); người có tiền sử gia đình có người mắc bệnh về tâm thần; gia đình không hạnh phúc. Đặt ra yêu cầu cần phát hiện sớm các đối tượng nguy cơ mắc trầm cảm nhằm can thiệp kịp thời, giảm thiểu đến mức thấp nhất hậu quả xảy ra. Việc xây dựng mạng lưới y tế chăm sóc sức khỏe tâm thần dựa vào cộng đồng với sự tham gia của người dân, nhân viên y tế, chính quyền địa phương là vấn đề nên được quan tâm.

\section{TÀI LIỆU THAM KHẢO}

1. Nguyễn Thanh Cao (2013), Thực trạng trầm cảm và một số yếu tố nguy cơ đến trầm cảm ở nqười trưởing thành tai phường Sông Cầu, thi xã Bắc Kạn năm 2011 và đề xuất một số giải pháp, Luận án chuyên khoa cấp II, Trường đại học y dược Thái Nguyên, Thái Nguyên.

2. Kìm Bảo Giang và Nguyễn Nguyên Ngọc (2013), "Biểu hiên trầm cảm và môt số yếu tố liên quan tai 6 xã (phường) thuộc Hà Nội-Thừa Thiên Huế-Cần Thơ năm 2012", Tạp chí y học thực hành, 879(9), tr. 41-44.

3. Trân Như Minh Hằng và cộng sự (2011), "Khảo sát tỳ lệ hiên mắc và đánh giá sưu thay đồ nhận thức trong trầm cảm qua thang khảo sát bộ ba nhâan thức ở người trưởng thành", Tạp chí y học thực hành, 792(11), tr. 34-38.

4. Bừi Quang Huy (2016), Trầm cảm, Nhà xuất bản y hooc, Hà Nội.

5. Nguyến Thị Thanh Mai (2011), "Nghiên cứu theo dôi doc sư' thay đổi của trầm cảm ở cha me trẻ bị ung thư trong quá trình điều trị", Tạp chí y học thực hành, 765(5), tr. 13-16.

6. Vương Văn Tỉnh (2011), "Một số nhâan xét về dịch tể bệnh trầm cam", Tạp chí y học thực hành, 732(9), tr. $17-19$.

7. Kurt Kroenke, Robert L. Spitzer và Janet B. W. Williams (2001), "The PHQ-9 Validity of a Brief Depression Severity Measure", J Gen Intern Med, 16, tr. pp. 606-613.

8. Laura Manea, Simon Gilbody và Dean McMillan (2015), "A dianostic meta-analysis of Patient Health Questionnaire 9 (PHQ-9)", General Hospital Psychiatry, 37, pp. 67-75.

\section{PHÂN LOẠI CHẨN ĐOÁN BỆNH NHÂN ĐAU THẮT LƯNG ĐƯỚC ĐIỀU TRI TAI PHÒNG CHÂM CỨU NGOAI TRÚ BỂNH VIÊ̂N ĐA KHOA Y HỌC CỔ TRUYỀN HÀ̀ NộI}

\section{Nguyễn Thị Thanh Tú*, Cao Thị Huyền Trang*}

\section{TÓM TẮT}

Mục tiêu: Khảo sát phân loại chẩn đoán theo y học hiện đại và y học cổ truyền trên bệnh nhân đau thắt lưng tại phòng Châm cứu ngoại trú - Bệnh viện Đa khoa $Y$ học cổ truyền Hà Nội. Đối tượng và

\footnotetext{
*Trường Đại học Y Hà Nội

Chịu trách nhiệm chính: Nguyễn Thị Thanh Tú

Email: thanhtu@hmu.edu.vn

Ngày nhận bài: 5.3.2021

Ngày phản biện khoa học: 26.4 .2021

Ngày duyệt bài: 7.5.2021
}

phương pháp: Nghiên cứu tiến cứu, mô tả cắt ngang. Chọn tất cả các bệnh nhân đau thắt lưng vào điêu trị ngoại trú từ tháng $01 / 2019$ đến tháng 09/2019. Kết quả: Trong thời gian nghiên cứu, phòng Châm cứu ngoại trú Bệnh viện Đa khoa đã điều trị cho 150 bệnh nhân. Về phân loại chẩn đoán, đại đa số bệnh nhân đau thắt lưng cấp $(72 \%)$, nguyên nhân cơ học chiếm chủ yếu $(87,33 \%)$. Trong đó tỉ lệ bệnh nhân thể can thận hư kết hợp hàn thấp chiếm phần lớn (32\%). Kết luận: Nghiên cứu đã cung cấp những thông tin liên quan đến phân loại chẩn đoán theo y hoc hiên đai và y hoc cổ truyền, giúp phòng châm cứu ngoại trú bênh viện đa khoa YHCT Hà Nội có cái nhìn nhận tổng quát, đây đủ về chẩn đoán bệnh đau thắt 